Kodifikasia : Jurnal Penelitian Islam, Vol 14, No. 01 (2020), 43-70

DOI : 10.21154/kodifikasia.v14i1.1906

ISSN : 1907-6371 (Cetak)

ISSN : 2527-9254 (Online)

\title{
GLOKALISASI PENDIDIKAN: STUDI ATAS REVITALISASI PEMIKIRAN KI HAJAR DEWANTARA
}

\author{
Hawwin Muzakki*
}

\begin{abstract}
ABSTRAK:
Adanya inferiority complex yang menjangkiti kaum pribumi dan paham koloni dari Belanda pada masa penjajahan, akhirnya ajaran diferensiasi sosial masuk ke masyarakat Indonesia. Belanda dengan sengaja membedakan antara pribumi dan non pribumi, sehingga mencabut akar identitas bangsa. Dalam kondisi tersebut, diperlukan sebuah lembaga pendidikan model baru yang bisa diakses oleh semua orang dengan menggabungkan tradisi luhur dan modernitas. Taman siswa (1922), sebagai jawaban Ki Hajar Dewantara atas lembaga pendidikan yang dimaksud. Penelitian ini merupakan penelitian literatur yang dianalisis dengan menggunakan hermeneutika filosofis. Penelitian ini ingin mengungkap, konsep pemikiran pendidikan Ki Hajar Dewantara berbasis kearifan lokal dan berwawasan global serta revitalisasi pemikiran glokalisasi pendidikan. Tujuan penelitian ini untuk memberikan gambaran pemikiran Ki Hajar Dewantara tentang konsep pendidikan yang masih melestarikan tradisi, mengembangkan modernitas, rancang bangun konseptual tersebut sebagai dasar untuk merevitalisasi pemikiran Ki Hajar Dewantara tentang pendidikan di Indonesia. Penelitian ini menghasilkan kesimpulan; Pertama, konsep pemikiran pendidikan Ki Hajar Dewantara berbasis kearifan lokal meliputi 3 hal, yaitu: local assets, traditions, values and beliefs. Kedua, konsep pemikiran pendidikan Ki Hajar Dewantara berwawasan global meliputi: Bidang ekonomi, bidang sosio-cultural dan bidang akademik. Ketiga, revitalisasi pemikiran Ki Hajar Dewantara tentang glokalisasi pendidikan, yaitu: revitalisasi aspek global dan revitalisasi aspek lokal dengan perencanaan glokalisasi pendidikan melalui: Komitmen kelembagaan; pembentukan kelompok perencanaan strategis dan komite pengarah, Penilaian kontekstual; Mengembangkan rencana strategis, Validasi; Adopsi dan Perayaan.
\end{abstract}

Kata Kunci: Glokalisasi Pendidikan; Hermenutika Filosofis; Ki Hajar Dewantara

\footnotetext{
* Institut Agama Islam Negeri Ponorogo, email : hawwin100@gmail.com
} 


\begin{abstract}
:
During the Dutch colonial period, The Netherlands deliberately distinguishes between natives and non-natives, thereby eliminating national identity. Under these conditions, a new model of educational institution is needed that can be accessed by everyone by combining the noble tradition and modernity. Taman Siswa (1922) is the answer of Ki Hajar Dewantara to the educational institution that intended. This research is a literature research that analyzed by using the philosophical hermeneutics. This research reveal, First, how is the concept of Ki Hajar Dewantara on education thought based on the local wisdom? Second, how is the concept of Ki Hajar Dewantara on the educational of global-minded? Third, how is the revitalization of Ki Hajar Dewantara's thoughts on the education glocalization? The purpose of this study is to provide a description of Ki Hajar Dewantara's thoughts on education glocalization (global, local and revitalizing aspects of his ideas). The results of this study concluded; First, the concept of Ki Hajar Dewantara education thought based on local wisdom includes 3 types, namely: local assets, traditions, values and beliefs. Second, the concept of global education Ki Hajar Dewantara's thinking includes: Economic, sociocultural and academic. Third, the revitalization of Ki Hajar Dewantara's thoughts on the education glocalization, namely: revitalizing global aspects and revitalizing local aspects with the planning of education glocalization through: Institutional commitment; the formation of a strategic planning group and steering committee, contextual assessment; Develop a strategic plan, Validation; Adoption and Celebration.
\end{abstract}

Keywords: Educational Glocalization; Philosophical Hermenutics; Ki Hajar Dewantara

\title{
PENDAHULUAN
}

Era modern ini, dampak globalisasi pada akhirnya memunculkan kecenderungan pembentukan budaya global yang menghilangkan identitas lokal. Globalisasi melahirkan budaya tanpa jiwa, karena didalamnya terdapat faham materialisme, sehingga orang kehilangan identitasnya. Sektor pendidikan juga mendapat pengaruh kuat dari globalisasi, dengan munculnya sekolah luar negeri yang membuka cabang di Indonesia semisal Harvard dan Cambridge University. 
Indonesia menjadi pihak yang ter-hegemoni, dari pada meng-hegemoni oleh globalisasi. Globalisasi membawa wajah pendidikan Indonesia khususnya, begitu dekat dengan kecanggihan teknologi, kemajuan berfikir dan arsitekturnya yang megah. Namun pilihan kepada globalisasi bukan tanpa resiko, membuat lembaga pendidikan di Indonesia menjauh dari tradisi kita dan membuat kita kehilangan jatidiri. Selain itu, globalisasi apabila tidak disaring akan membawa paham yang bersebrangan dengan nilai-nilai local wisdom semisal materialisme, imperialisme dan kolonialisme.

Sejarah pendidikan Indonesia mencatat, pasca politik balas budi yang dilakukan pihak Belanda melalui gubernur Van Der Venter. Belanda membuka secara lebar namun terbatas, akses pendidikan terhadap kaum pribumi. Produk pendidikan model belanda, akhirnya hanya akan melahirkan sesosok pribumi birokrat, yang bekerja di binnenlands bestuur (BB) untuk menjadi mantri, asisten wedana, wedana, dan bupati untuk membantu pemerintahan koloni. Pendidikan Belanda hanya bisa diikuti oleh golongan priyayi yang kaya, melahirkan lulusan yang intelektualis, individualis dan materialis dengan meninggalkan budaya lokal masyarakat Indonesia. ${ }^{1}$

Adanya inferiority complex yang menjangkiti kaum pribumi dan paham koloni dari Belanda, akhirnya ajaran diferensiasi sosial masuk ke masyarakat. Belanda dengan sengaja membedakan antara masyarakat pribumi dan non pribumi, antara kelas santri dan abangan. ${ }^{2}$ Sehingga merusak dan mencabut akar identitas bangsa Indonesia, serta menyulitkan masyarakat untuk mencapai kemerdekaan secara penuh. Dalam kondisi tersebut, diperlukan sebuah lembaga pendidikan model baru yang bisa diakses oleh semua orang, berjiwa nasionalis, berfikir merdeka, dengan menggabungkan tradisi luhur dan modernitas yang ada.

Ki Hajar Dewantara merasa gelisah dan berfikir, bagaimana masyarakat Indonesia menjadi insan yang otonom secara intelektual (tidak dihegemoni oleh belanda), sosial (gotong royong) dan eksistensial (merdeka dan mengembangkan jati diri bangsa). Taman siswa yang berdiri Tahun 1922, sebagai jawaban Ki Hajar Dewantara atas lembaga pendidikan yang menjadi basis perjuangan kemerdekaan. ${ }^{3}$

Indonesia abad 19, banyak tumbuh dan berkembang lembagalembaga pendidikan, semisal lembaga bentukan belanda (MULO, HIS, STOVIA), Pesantren, Muhammadiyah dan Taman Siswa. Perbedaannya,

${ }^{1}$ Sartono Kartodirdjo, Pengantar Sejarah Indonesia Baru Sejarah Pergerakan Nasional (Jilid 2) (Yogyakarta: Penerbit Ombak, 2014), 38.

${ }^{2}$ Kartodirdjo, 94.

${ }^{3}$ Marwati Djoened Poesponegoro and Nugroho Notosusanto, Sejarah Nasional Indonesia V (Jakarta: PN Balai Pustaka, 1984), 244. 
Muhammadiyah menerima modernitas dan menolak tradisi (purifikasi Islam), Pesantren menolak modernitas dan menerima tradisi.Lembaga pendidikan belanda mengembangkan modernitas dan menolak tradisi bahkan melakukan diferensiasi sosial. Perguruan Taman Siswa menerima tradisi lokal (jawa) dan mengembangkan modernitas (pemikiran dari Barat/ Eropa). Ki Hajar Dewantara dengan taman siswanya punya ciri khas khusus yang tidak dimiliki oleh lembaga lain. Taman siswa berhasil menyatukan pendidikan dan kebudayaan, melawan modernitas yang menghegemoni kala itu. ${ }^{4}$

Kegelisahan penulis untuk menyelidiki pemikiran utama Ki Hajar Dewantara mengenai penyatuan pendidikan dan kebudayaan, ditemukan dalam konsep yang digagas oleh Ki Hajar Dewantara didua buku utama yang berjudul Karya Ki Hajar Dewantara bagian pertama pendidikan dan bagian kedua kebudayaan. Pemilihan redaksi ketika menjadi menteri pendidikan dan kebudayaan, dari pada memilih menteri pendidikan nasional mengarah kepada pendamaian dua problematika besar kala itu.

Berdasarkan eksplorasi peneltian tentang Glokalisasi Pendidikan: Studi atas Revitalisasi Pemikiran Ki Hajar Dewantara, penulis berkesimpulan bahwa belum ada kajian yang secara langsung membahas tentang konsep glokalisasi pendidikan yang dibangun oleh Ki Hajar Dewantara. Penelitian yang dilakukan oleh Pay Fetel ${ }^{5}$ mengarahkan kepada perkembangan glokalisasi di Perguruan Tinggi. Sedangkan penelitian yang dilakukan oleh Khoirul Mudawinun Nisa'6, menjadikan kerangka berfikir GED (konsep dari Pay Fetel) untuk melihat glokalisasi yang ada di pondok pesantren. Adapun gagasan besar Ki Hajar Dewantara mengenai konsep glokalisasi pendidikan belum ditemukan dalam kedua penelitian tersebut.

Melalui pembacaan hermeneutika filosofis, penulis ingin merevitalisasi pemikiran pendidikan Ki Hajar Dewantara. Rumusan masalah dalam penelitian ini untuk menyelidiki: Pertama, Bagaimana konsep pemikiran pendidikan Ki Hajar Dewantara berbasis kearifan lokal? Kedua, Bagaimana konsep pemikiran pendidikan Ki Hajar Dewantara berwawasan global? Ketiga, Bagaimana revitalisasi pemikiran Ki Hajar Dewantara tentang glokalisasi pendidikan, menggunakan teori hermeneutika filosofis?Adapun tujuan dalam penelitian ini untuk Memberikan gambaran pemikiran Ki

${ }^{4}$ Poesponegoro and Notosusanto, 248-49. Lihat juga Hawwin Muzakki and Khoirul Mudawinun Nisa', "Basis Transformasi Tradisi Pesantren Salaf Di Era Modern (Kajian Semiotika Barthes Dan Dekonstruksi Derrida)," QALAMUNA: Jurnal Pendidikan, Sosial, Dan Agama 12, no. 01 (2020): 91-105, https://doi.org/10.37680/qalamuna.v12i01.304.

${ }_{5}$ Pay Fetel, "Deconstructing Internationalization: Advocating Glocalization in International Higher Education," Journal of International and Global Studies 8, no. 2 (2017).

${ }^{6}$ Khoirul Mudawinun Nisa, "Glokalisasi: Membangun Pendidikan Global Berbasis Kearifan Lokal pada Pondok Modern,” AN-NUHA 5, no. 1 (2018).

Kodifikasia: Jurnal Penelitian Islam, Volume, 14 No. 1 Tahun 2020 
Hajar Dewantara tentang konsep pendidikan yang masih melestarikan tradisi, mengembangkan modernitas, rancang bangun konseptual tersebut sebagai dasar untuk me-revitalisasi pemikiran Ki Hajar Dewantara tentang pendidikan di Indonesia dalam melestarikan budaya lokal dan menjawab tantangan modernitas.

Secara umum penelitian ini diharapkan memberikan konstribusi bagi: Pertama, pengembangan teori hermeunetika teoritis yang diimplementasikan untuk merevitalisasi pemikiran Ki Hajar Dewantara. Kedua, bisa memberikan kritik dan penyadaran terhadap sebagian praktek Pendidikan yang meninggalkan tradisi atau lembaga pendidikan yang tidak mengembangkan modernitas dalam kurikulumnya. Ketiga, bisa menjadi dasar pengembangan glokalisasi pendidikan dengan tokoh lokal, Ki Hajar Dewantara.

Jenis penelitian ini merupakan penelitian literatur. Obyek penelitian ini adalah konsep dan pemikiran Ki Hajar Dewantara tentang pendidikan dan kebudayaan. Pustaka primer dalam penelitian ini meliputi karya Ki Hajar Dewantara yaitu Karya Ki Hajar Dewantara: Bagian Pertama, (Pendidikan) (1967); Karya Ki Hajar Dewantara bagian kedua A (Kebudayaan) (1967);

Peneliti menggunakan teori hermeneutika filosofis dengan meminjam empat langkah metodologis yang digagas oleh Amin Abdullah. Susunan langkah tersebut, diantaranya: Pertama, mencari kegelisahan akademik yang melatarbelakangi penulis menuangkan gagasan besarnya dalam sebuah karya atau buku. Kedua, kegelisahan akademik tersebut menentukan sang penulis dalam merumusakan masalah dan batasan masalah yang menjadi bidang objek kajiannya. Ketiga, mengungkap dan menelaah tujuan penulisan dan kontribusi keilmuannya. Keempat, menelusuri penggunaan metode, pendekatan dan teori yang digunakan penulis untuk mengungkapkan

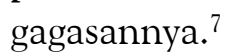

Hermeneutical Philosophy lebih mencermati dimensi filosofis-fenomenologis pemahaman. Pertanyaannya bukanlah mengenai \apa yang kita lakukan atau apa yang seharusnya kita lakukan akan tetapi apa yang terjadi di luar kemauan atau studi dan pekerjaan kita. Singkatnya, hermeneutical philosophy lebih jauh lagi dengan menggali asumsi-asumsi epistemologis dari penafsiran dengan masuk ke dalam aspek historisitas tidak hanya dalam dunia teks akan tetapi juga dunia pengarang dan juga dunia pembacanya. ${ }^{8}$

${ }^{7}$ M. Amin Abdullah, "Pendekatan Hermeneutik Dalam Studi Fatwa-Fatwa Keagamaan,” in Atas Nama Tuhan, trans. R. Cecep L (Jakarta: Serambi Ilmu Semesta, 2004), 179.

${ }^{8}$ Muhammad Muchlish Huda, "Fisibilitas Hermeneutika dalam Penafsiran AlQur'an," Dialogia 12 (2014): 75-76. Juga lihat Iswahyudi, "ITTISHÂL AL-WUJÛD Telaah Hermeneutis Atas Ajaran Mistik Al-Fârâbî,” Dialogia, n.d., 149. Dan Abid Rohmanu, 
Langkah-langkah yang digunakan untuk membaca Ki Hajar Dewantara melalui pembacaan hermeneutika filosofis, yaitu: Pertama, Kesadaran mengenai "situasi hermeneutik" yang berbeda dengan penulis, keterbatasan ini membuat pembaca tidak bisa melepaskan diri dari tradisinya. Kedua,pra-pemahaman yang membentuk pemahaman pembaca teks dan mendialogkannya dengan konteks. Ketiga,menggabungkan dua horizon, yaitu horizon pembaca dan teks, interaksi dua horizon ini oleh gadamer disebut "lingkaran hermeneutik". Keempat,menerapkan "makna yang berarti" dari teks yang mempunyai nilai bagi pembaca. ${ }^{9}$

\section{PEMBAHASAN}

\section{Biografi Ki Hajar Dewantara}

Ki Hajar Dewantara bernama asli Suwardi Suryaningrat, lahir di Yogyakartanpada Kamis Legi 2 Puasa 1818, atau 2 Mei 1889, 1303 H, dan meninggal pada 26 April 1959 bertepatan dengan $1376 \mathrm{H}$ (dengan usia 70 tahun). Ki Hajar adalah putra dari Kanjeng Pangeran Haryo Suryaningrat, putra Kanjeng Gusti Pangeran Hadipati Haryo Suryo Sasraningrat yang bergelar Sri Paku Alam III. Sebagai seorang keluarga ningrat, ia orang yang beruntung dalam hal pendidikan pada masa penjajahan Belanda kala itu, walaupun kemudian beliau sakit sehingga tidak dapat mengkhatamkan studinya. ${ }^{10}$

Alumnus sekolah rendah Belanda (Euro peesche Lagere School, ELS) lulus pada tahun 1904. Kemudian menempuh Sekolah Guru (Kweek School) di Yogyakarta pada tahun 1905, tetapi sebelum sempat menyelesaikannya, ia mendapatkan beasiswa menempuh pendidikan ke Stovia (School tot Opleiding van Indische Arten) pada tahun 1910. Di Stovia ternyata juga tidak lulus, dikarenakan sakit.

Atas keahliannya berbahasa Belanda, yang pada waktu itu orang yang bisa berbicara bahasa Belanda punya kedudukan yang istimewa, ia mendapat surat keterangan istimewa dari direktur Stovia. Kemudian Ki Hajar Dewantara belajar sebagai polenter pada laboratorium pabrik gula serta menjadi pembantu apoteker di apotek Rath-Camp Yogjakarta, sambil kerja sampingannya membantu di surat-surat kabar antara lain: Sedyo Tomo, Midden Java dan De Expres.

\footnotetext{
"Human Agent dalam Tradisi Fikih: Studi Relasi Hukum Islam Dan Moralitas Perspektif Abou El Fadl," Kodifikasia, 7, no. 1 (2013): 16-17.

9 Aksin Wijaya, Teori Interpretasi Al-Qur'an Ibnu Rushd Kritik Ideologi-Hermeneutis (Yogyakarta: Kalimedia, 2017), 39. Lihat juga Muhammad Tasrif, "METODOLOGI FIQH AL-HADÎTH Telaah Hermeneutik Terhadap Pandangan Yûsuf Al-Qardâwî," Dialogia, n.d., 222.

${ }^{10}$ Ahmad Syaikhudin, "Konsep Pemikiran Pendidikan Menurut Paulo Freire dan Ki Hajar Dewantoro," Cendekia 10, no. 1 (2012): 80-81.
}

Kodifikasia: Jurnal Penelitian Islam, Volume, 14 No. 1 Tahun 2020 
Nama Ki Hajar dapat dikategorikan sebagai tokoh muda yang mendapat perhatian Cokroaminoto, untuk memperkuat barisan Syarikat Islam. Bersama Wignyadisastra (ketua), Abdul Muis (wakil ketua), yang dan Ki Hajar Dewantara (sekretaris). Tidak lama kemudian, ia bersama dengan Douwes Dekker dan Cipto Mangunkusumo, ia diasingkan ke Belanda (1913) karena orientasi politik mereka yang radikal.

Sedangkan karya yang ditulis langsung oleh Ki Hajar Dewantara, yakni buku yang berjudul:

1. Karya Ki Hajar Dewantara: Bagian Pertama Pendidikan, Yogyakarta: Percetakan Tamansiswa, 1962;

2. Karya Ki Hajar Dewantara: Bagian Kedua Kebudayaan, Yogyakarta: Percetakan Taman Siswa, 1964;

3. Taman Indrya (Kindergarten), Yogyakarta: Majlis Luhur Tamansiswa, 1959;

4. Asas-asas dan Dasar-dasar Tamansiswa, Yogyakarta: Majlis Luhur Tamansiswa, 1961;

5. Demokrasi dan Leiderschap, Yogyakarta: Majelis Luhur Tamansiswa, 1959;

6. Pengaruh Keluarga terhadap Moral, Jakarta: Endang, 1951;

7. Kenang-kenangan Ki Hajar Dewantara: dari Kebangunan Nasional sampai Proklamasi Kemerdekaan, Jakarta: Penerbit Endang, 1952.

Dari biografi tersebut kita dapat memahami mengenai sejarah, latar belakang pemikiran serta organisasi yang diikuti Ki Hajar. Masa penjajahan yang dialami dan dirasakan langsung oleh Ki Hajar, serta sedikitnya masyarakat pribumi yang mengenyam pendidikan, membentuk konsep strategis penentangan penjajahan yang dilakukannya melalui jalur pendidikan dan organisasi kemasyarakatan semisal Serikat Islam dan Indij Partij, dengan tidak memilih jalur perang. Kepandaian ia dalam dunia tulis menulis serta pengalamannya dalam membuat berita dalam beberapa koran, menjadi salah sate faktor Suwardi Suryaningrat begitu produktif dalam berkarya.

\section{Aspek Pengembangan Local dalam Pemikiran Ki Hajar Dewantara}

Kearifan lokal atau tradisi sesungguhnya merupakan bagian dari etika dan moralitas, yang membantu manusia untuk menjawab pertanyaan moral apa yang harus dilakukan? bagaimana harus bertindak? Mengapa berbuat demikian?. Kearifan lokal adalah semua bentuk pengetahuan, wawasan, keyakinan serta adat kebiasaan atau etika yang menuntut perilaku manusia dalam kehidupannya. Nilai-nilai kearifan lokal yang terkandung dalam suatu sistem sosial masyarakat, dapat di hayati, dipraktikkan, diajarkan, 
dan diwariskan dari suatu generasi ke generasi lainnya yang sekaligus membentuk dan menuntun pola perilaku manusia sehari-hari, baik terhadap alam maupun lingkungan dan sangat berpengaruh dalam aspek pendidikan di suatu wilayah. ${ }^{11}$

Keterangan mengenai pengembangan kearifan lokal pada pembahasan ini sebagai basis awal pembaca untuk memahami pemikiran Ki Hajar Dewantara mengenai glokalisasi. Pengertian lain mengatakan, kearifan lokal merupakan semua kecerdasan-kecerdasan lokal yang ditranformasikan ke dalam cipta, karya dan karsa sehingga masyarakat dapat mandiri dalam berbagai iklim sosial yang terus berubah-ubah. Lokalitas dimaknai sebagai melindungi dan menghargai tiga faktor penting, yaitu: lokal aset, tradisi, nilaidan kepercayaan lokal. Tiga faktor inilah yang penulis jadikan acuan untuk menggali aspek lokalitas dari pemikiran Ki Hajar Dewantara. ${ }^{12}$

Faktor pembentuk yang pertama adalah local assets. Lokal aset dalam pemikiran Ki Hajar Dewantara dan yang tertuang dalam lembaga taman siswa yaitu mengembangkan bahasa jawa baik secara lisan maupun tulisan. Karena aspek bahasa ini yang sangat berpengaruh kelak terhadap pengembangan pendidikan seorang anak. Dalam "bahasa" ada struktur, unggah ungguh, serta aksara yang dapat mempertahankan kebudayaan asli Indonesia. Selain itu, Ki Hajar Dewantara selalu mengingatkan kita, pentingnya menjadi manusia dengan kodratnya sebagai "manusia Jawa". Jadi produk-produk, prinsip-prinsip pendidikan di Taman Siswa menggunakan bahasa dan kodrat orang jawa, mulai dari model pengasuhan yang berupa among system, walaupun diluar sudah mengenal education, pendidikan atau pengajaran. Ki Hajar Dewantara tetap mengenalkan konsep pendidikan lokal, yaitu; momong, among, dan ngemong yang diibaratkan seperti kita mendidik anak kecil dengan tulus, kasih sayang dan dengan kebebasan. ${ }^{13}$

Kedua, Tradisi. Konsep tradisi dalam pemikiran Ki Hajar Dewantara dan yang tertuang dalam lembaga taman siswa yaitu mengembangkan pola permainan tradisional khas jawa. Mulai dari gobag sodor, delik-delikan, loncat tali, dakon, dan permainan tradisional lainnya dalam upaya terus mempertahankan kebudayaan Indonesia, agar tidak tergerus oleh arus

${ }^{11}$ Nihayatur Rohmah, "Akulturasi Islam dan Budaya Lokal (Memahami Nilai-Nilai Ritual Maulid Nabi Di Pekalongan)," Al-Mabsut: Jurnal Studi Islam Dan Sosial 9, no. 2 (2015): 2. Lihat juga Salsabilah, "Pendidikan Karakter Islami Berbasis Nilai-Nilai Kearifan Lokal (Penelitian Di SDN 12 Ciseureuh Kahuripan Pajajaran Purwakarta)," Cendekia 17, no. 2 (2019): 274.

${ }^{12}$ Emmanuel Jean Francois, Building Global Education With A Local Perspective: An Introduction To Glocal Higher Education (New York: Palgrave Macmillan, 2015), 89.

${ }^{13} \mathrm{Ki}$ Hadjar Dewantara, Karya Ki Hadjar Dewantara Bagian Pertama: Pendidikan (Yogyakarta: Yayasan Persatuan Tamansiswa, 2011), 13-14.

Kodifikasia: Jurnal Penelitian Islam, Volume, 14 No. 1 Tahun 2020 
globalisasi, akhirnya menghilangkan jati diri bangsa Indonesia. Permainan tradisional itu diajarkan di lembaga Taman Siswa.

Selain itu, juga diajarkan aneka kesenian daerah berupa gending, wayang, musik bonang, tari-tarian jaipong, srimpi, tonil, ajaran wirama, dan lain sebagainya. Bahkan dalam taman siswa diajarkan dengan sistem sariswara yaitu sistem bergabungnya bahasa, lagu dan cerita yang digabung dalam sebuah pelajaran. ${ }^{14}$ Semua itu bertujuan agar dapat menyatunya jiwa anak-anak kita dengan jiwa masyarakatnya, walaupun mendapat tantangan dan tergerus mulai masuknya ajaran musik dansa dari Belanda. Ada sebuah peristiwa kala itu, orang sangat bangga berdansa dan malu bertari jaipong. Menganggap dansa lebih tinggi dan mewah dibanding tari jaipong. Sehingga Ki Hajar Dewantara tetap bersikukuh untuk terus mempertahankan tradisi jawa yang ada di Indonesia.

Ketiga, nilai dan kepercayaan. Nilai dan kepercayaan lokal dalam pemikiran Ki Hajar Dewantara dan yang tertuang dalam lembaga taman siswa yaitu dalam jargon atau pitutur luhur yang digagas oleh Ki Hajar Dewantara. Jargon atau pitutur luhur ini juga merupakan gagasan besar dari Ki Hajar Dewantara sebagai seorang pendidik, semisal:

a. Momong, among dan ngemong. Momong, among dan ngemong yang berarti bahwa pendidikan itu bersifat mengasuh. Mendidik adalah mengasuh anak dalam dunia nilai-nilai. Dalam prakteknya memang menertibkan, namun bukan lewat jalan kekerasan, melainkan dengan jalan kesadaran sesuai dengan kodratnya. Maka, pembagian usia 0-7, 7-14, dan 14-21 dan jenjang pendidikan (Taman Indriya, Taman Anak, Taman Muda, Taman Madya dan Taman Dewasa) dalam proses pendidikan yang digagas Ki Hajar Dewantara bukan tanpa landasan pedagogik. Pembagian demikian berdasarkan fase-fase di mana masingmasing menuntut peran pendidik dengan isi dan nilai yang berbedabeda..$^{15}$

b. Tetep, antep dan mantep, ketetapan fikiran dan batin. Ketika sudah tetep maka akan menentukan kualitas seseorang, dan kemantapan fikiran dan batin akan datang, tidak akan goyah. ${ }^{16}$

c. Ngandel, kandel, kendel dan bandel, jika percaya akan pendirian yang tegak maka keberanian akan muncul dan pantang takut kemudian untuk menegakkan keadilan. ${ }^{17}$

${ }^{14} \mathrm{Ki}$ Hadjar Dewantara, Karya Ki Hadjar Dewantara Bagian II: Kebudayaan (Yogyakarta: Yayasan Persatuan Tamansiswa, 2011), 24.

${ }^{15}$ Dewantara, Karya Ki Hadjar Dewantara Bagian Pertama: Pendidikan, 13.

${ }^{16}$ Dewantara, 14.

${ }^{17}$ Dewantara, 14. 
d. Neng, ning, nung dan nang, kesucian fikiran dan batin yang didapat dari ketenangan hati, itulah yang mendatangkan kekuasaan. ${ }^{18}$

e. Ing ngarso sung tulodho, ing madyo mangunkarso, tut wuri handayani. Pertama, Ing Ngarsa Sung Tuladha, artinya seorang guru adalah pendidik yang harus memberikan sebuah suri tauladan yang baik. Dengan memberikan banyak perbuatan baik dari pada hanya sekedar memberi contoh. Kedua, Ing Madya Mangun Karsa, artinya seorang guru adalah pendidik yang selalu berada di tengah-tengah para muridnya dengan memberikan motivasi untuk banyak meraih berprestasi. Ketiga, Tut Wuri Handayani, artinya seorang guru adalah pendidik yang terus-menerus mendorong dan menunjuk arah yang benar bagi hidup dan karya peserta didiknya.

Aspek yang lain soal nilai dan kepercayaan semisal "moral ketimuran" mengenai adab, unggah-ungguh, adat istiadat lokal Indonesia serta pengembangan ilmu jiwa (aspek psikologi) yang dikembangkan konsepnya oleh Ki Hajar Dewantara yang berguna bagi keluarga Indonesia, sehingga tidak mudah terbawa arus globalisasi. ${ }^{19}$

\section{Aspek Pengembangan Global dalam Pemikiran Ki Hajar Dewantara}

Globalisasi merupakan sebuah gerakan dunia yang menghadirkan 2 sisi yang berbeda tetapi saling terkait. Di satu sisi, globalisasi telah menghadirkan pemikiran yang mengarahkan dunia menjadi semakin seragam dan terstandar melalui penyesuaian teknologi, kebudayaan dan perdagangann dari dunia Barat. Tetapi di sisi lain globalisasi meningkatkan sensitifitas terhadap perbedaan budaya antar bangsa sehingga memungkinkan terjadinya proses clash of civilization.

Globalisasi berkaitan erat dengan modernisasi, yang dalam perkembangannya telah melahirkan efek-efek positif, misalnya rasionalisasi, standarisasi dan kontrol, namun demikian modernisasi juga melahirkan efek-efek negatif, misalnya alienasi, ketidakpuasaan, ketidakstabilan atau perubahan yang terjadi secara terus menerus. ${ }^{20}$

Globalisasi mengacu pada fenomena yang menghubungkan orang di seluruh dunia dengan cara yang berbeda dan baru (misalnya: media

${ }^{18}$ Dewantara, 14.

${ }^{19}$ Hawwin Muzakki, "Relasi Pendidikan (Agama) Dan Kebudayaan," Proceedings of Annual Conference for Muslim Scholars 3, no. 1 SE-Articles (November 26, 2019): 746-47, http://proceedings.kopertais4.or.id/index.php/ancoms/article/view/287.

${ }^{20}$ Moh. Miftachul Choiri and Aries Fitriani, "PROBLEMATIKA PENDIDIKAN ISLAM SEBAGAI SUB SISTEM PENDIDIKAN NASIONAL DI ERA GLOBAL," AlTahrir 11, no. 2 (2011): 318. Lihat juga Moh Miftachul Choiri, "Quo Vadis Pendidikan Multikultural Dalam Era Global Di Pesantren,” Cendekia 9, no. 2 (2011): 382-83.

Kodifikasia: Jurnal Penelitian Islam, Volume, 14 No. 1 Tahun 2020 
massa, teknologi, dan sistem transportasi modern) melalui hubungan saling ketergantungan di antara negara, budaya, orang, dan masyarakat. Globalisasi juga terjadi dalam dunia politik, ekonomi, masyarakat, politik, pendidikan dan budaya. Aspek pengembangan globalisasi dari pemikiran Ki Hajar Dewantara merupakan akibat adanya hegemoni yang besar dari negara lain, sehingga melakukan perlawanan. Semua konsep perlawanan tentang globalisai tertuang dalam pemikirannya dan terlaksana dalam Taman siswa yaitu:

Bidang ekonomi: Mempertahankan konsep gotong royong. Individualisme khas pendidikan Belanda jelas menentang ajaran gotong royong yang membudaya di masyarakat Indonesia. Belanda dengan VOCnya hadir ke Indonesia mengusung politik kapitalisme. Bagaimana kekayaan pribadi dan hak milik pribadi dikedepankan dari pada kepentingan umum. Sering kehidupannya hanya untuk memikirkan keahagiaan dirinya sendiri, tanpa memikirkan bagaimana nasib orang yang terjajah. Lewat politik tanam paksa yang mengikat, mereka mewajibkan menanam tanamantanaman produktif yang siap dijual di pasar. Individualisme yang dibawa pendidikan oleh Belanda ditentang oleh Ki hajar Dewantara dengan menggagas komunitas-komunitas yang saling bekerja sama satu sama lain dan saling bergotong royong. Ki Hajar Dewantara aktif dalam organisasiorganisasi kemasyarakatan semisal Boedi Utomo sebagai seksi propaganda, Indische Partij bersama Douwes Dekker dan dr. Cipto Mangoenkoesoemo, tiga serangkai dan ketua serikat Islam cabang Bandung.

Menurut Ki Hajar Dewantara, manusia yang merdeka adalah manusia yang secara lahir dan batin tidak tergantung kepada orang lain, tetapi dengan bersandar pada kekuatan diri sendiri. Pengajaran bisa memerdekakan kita secara lahir, sedangkan pendidikan bisa memerdekakan kita secara batin. ${ }^{21}$ Prinsip pendidikan yang memerdekakan menurut Ki Hajar Dewantara yaitu: berdiri sendiri (zelfstandig), tidak bergantung pada orang lain (onafhankelijk), dan dapat mengatur dirinya sendiri (vrijheld, zelf beschikking).

Ketiga prinsip inilah yang selalu dipegang teguh oleh Ki Hajar Dewantara. Melalui pemikirannya tersebut dia melarang adanya subsidi dari pemerintah belanda pada kala itu, karena diyakini akan membuat hutang budi kepada yang memberi subsidi. Sehingga masyarakat yang diberi subsidi tidak berani untuk berontak, artinya dia tidak memiliki jiwa kemerdekaan. Hanya dengan berfikir merdeka, dan memegang prinsip "hanya boleh menerima subsidi dikala kita tidak terikat secara lahir dan batin", sehingga tidak mempengaruhi jiwa kemerdekaan kita. Pada akhirnya, melalui konsep gotong royong tersebut Ki Hajar Dewantara memilih jalan swasta dalam

\footnotetext{
${ }^{21}$ Dewantara, Karya Ki Hadjar Dewantara Bagian Pertama: Pendidikan, 3-4.
} 
mengembangkan perguruan Taman Siswa, agar tidak dapat pengaruh subsidi yang mengikat dari siapapun. Dengan aktif melibatkan peran serta masyarakat sekitar, untuk mengembangkan Taman Siswa ${ }^{22}$

Bidang sosio-cultural yaitu membrantas strata sosial melalui konsep persamaan drajat. Adanya inferiority complex yang menjangkiti kaum pribumi dan paham koloni dari Belanda, akhirnya ajaran diferensiasi sosial masuk ke masyarakat. Belanda dengan sengaja membedakan antara masyarakat pribumi dan non pribumi, antara kelas santri dan abangan. ${ }^{23}$ Sehingga merusak dan mencabut akar identitas bangsa Indonesia, serta menyulitkan masyarakat untuk mencapai kemerdekaan secara penuh. Dalam kondisi tersebut, diperlukan sebuah lembaga pendidikan model baru yang bisa diakses oleh semua orang, berjiwa nasionalis, berfikir merdeka, dengan menggabungkan tradisi luhur dan modernitas yang ada.

Taman siswa yang berdiri Tahun 1922, sebagai jawaban Ki Hajar Dewantara atas lembaga pendidikan yang menjadi basis perjuangan kemerdekaan. Semua pribumi yang tidak tercukupi pendidikannya, mungkin tidak mempunyai biaya sekolah, tidak dari golongan ningrat, masyarakat yang benci terhadap konsep pendidikan Belanda bisa menyekolahkan anaknya di Taman Siswa. Taman Siswa kala itu berhasil bersaing dengan pendidikan-pendidikan khas Belanda. Atas dasar persamaan derajat dan ingin menjunjung tinggi pendidikan pribumi, Taman Siswa berhasil berdiri dengan tegak di tengah-tengah masa kolonialisasi Belanda. ${ }^{24}$

Bidang akademik, yaitu:

1. Dengan mengajarkan bahasa belanda dalam Taman Siswa, ia sendiri termasuk tokoh yang bisa membaca dan menulis dalam bahasa Belanda, berdasarkan kary-karya yang telah dibuatnya.

2. Tokoh-tokoh modern pada masa itu, juga banyak yang mempengaruhi peikirannya semisal Frobel, Montessori, Tagore, Spencer, Steiner, Maria Montessori, Friedrich Wilhelm August Frõebel, Jean-Jacques Rousseau, Rudolf Steiner, Rabrindranath Tagore, Herbert Spencer, Johann Heinrich Pestalozzi. Bacaan-bacaan Barat yang luas, mempengaruhi pola pandangnya terhadap pendidikan yang tertuang dalam Taman Siswa.

3. Jenjang pendidikan taman siswa yang mirip dengan ajaran Belanda mulai dari Taman Indriya $<7$ tahun; Taman Anak pasca Taman Indriya kelas 1, 2, dan 3; Taman Muda 4. 5, dan 6; Taman Madya; Taman Dewasa.

${ }^{22}$ Dewantara, 5.

${ }^{23}$ Kartodirdjo, Pengantar Sejarah Indonesia Baru Sejarah Pergerakan Nasional (Jilid 2), 94.

${ }^{24}$ Marwati Djoened Poesponegoro and Nugroho Notosusanto, Sejarah Nasional Indonesia V (Jakarta: PN Balai Pustaka, 1984), 244.

Kodifikasia: Jurnal Penelitian Islam, Volume, 14 No. 1 Tahun 2020 
Berbeda dengan konsep pendidikan pesantren kala itu dengan tanpa jenjang dan batas usia.

4. Materi-materi yang diajarkan dalam taman siswa berupa pengembangan aspek kognitif (rasionalisme), afektif (adab ketimuran) dan psikomotorik (kejuruan). Berupa pengetahuan global dan lokal, tetap mempertahankan adat ketimuran dan mempunyai skill atau keahlian yang berguna pada masa itu. ${ }^{25}$

\section{Glokalisasi Pendidikan Perspektif Ki Hajar Dewantara}

Pembahasan kali ini, penulis akan mengargumenkan bagaimana glokalisasi pendidikan perspektif Ki Hajar Dewantara yang penulis gali melalui hermeneutika filosofis. Pada kesimpulan akhir nanti bahwa pemikiran Ki Hajar Dewantara mengenai glokalisasi pendidikan, teraplikasi pada Perguruan Taman Siswa yang sudah beliau praktekkan di Indonesia.

Taman siswa pernah mengalami puncak kejayaan pada Tahun 1920-an. Sejak berdiri tahun 1922 hingga 1930, artinya dalam masa pemerintahan Hindia Belanda, telah berdiri lebih dari 100 cabang Taman Siswa dari Sabang hingga wilayah Nusantara bagian timur Maluku, Kupang, dll. Maka, pada tahun 1930 berubah menjadi Persatuan Perguruan Taman Siswa yang berpusat di Mataram, Yogyakarta. Dengan 125 cabang, 294 lembaga, 1.764 Murid dan 50 guru.

Mengapa taman siswa menjadi model glokalisasi pendidikan khas Indonesia? Akan terjawab dalam uraian berikut ini:

\section{Taman Siswa: Produk Glokalisasi Pendidikan Perspektif Ki Hajar Dewantara}

Aktivitas berfikir merupakan proses yang membedakan antara manusia dan hewan. Sebuah definisi Arab mengaratakan, al-insanu hayawanu natiq, manusia adalah hewan yang berfikir. Dari proses berfikir terdapat pintu masuk antara pendidikan dan kebudayaan. Ada hubungan timbal balik yang sangat erat antara pendidikan dan kebudayaan.

Di satu sisi, sebuah konsep pendidikan berkembang pada suatu kebudayaan tertentu. Kebudayaan yang maju membuahkan dan menghasilkan pendidikan yang maju pula. Misalnya konsep pendidikan humanisme, pendidikan multikultural, pendidikan seumur hidup menandakan masyarakatnya mempunyai pola pemikiran serta kebudayaan yang maju dan berkembang.

${ }^{25}$ Dewantara, Karya Ki Hadjar Dewantara Bagian Pertama: Pendidikan. Lihat juga pengembangan aspek kognitif, afektif dan psikomotorik dalam Hawwin Muzakki, Sistem Penilaian Pembelajaran Teori Dan Praktek (Malang: Madani Media, 2019), 150-51. 
Di sisi lain akibat dari kemajuan pendidikan, mempengaruhi masyarakat sosial pada umumnya, sehingga pendidikan yang baik bertransformasi ke ranah sosial-masyarakat. Pendidikan berkontribusi terhadap transformasi kemajuan kebudayaan manusia, seperti munculnya sosok pemikir, alat-alat yang mutakhir, kemajuan dalam bidang seni dan sebagainya. Pada intinya, pola hubungan antara pendidikan dan kebudayaan adalah pendidikan untuk mempertahankan kebudayaan, serta kebudayaan untuk memajukan pendidikan.

Orientasi pendidikan yang digagas oleh Ki Hajar Dewantara fokus pada keseimbangan antara kebutuhan jasmani dan rohani untuk mencapai kebahagiaan yang sempurna di dunia dan akhirat. Globalisasi yang menghegemoni kala itu memerlukan kembalinya peran landasan moral, karakter, dan kepribadian dalam kehidupan, harus dipahami sebagai ajakan untuk kembali ke konsep nilai-nilai manusia yang berpusat pada hati, pikiran dan kepekaan sensorik yang meliputi penglihatan, pendengaran, penciuman dan rasa dari kebudayaan timur. ${ }^{26}$

Adanya denasionalisasi kebudayaan yang dilancarkan oleh Belanda, Ki Hajar dewantara memilih jalan pendidikan untuk menghalau bahaya tersebut. Mulai dari pendidikan keluarga, pendidikan masyarakat dan pendidikan yang terlembaga (tripusat pendidikan) dan penguatan jati diri sebagai manusia Indonesia ${ }^{27}$ Sehingga Ki Hajar Dewantara membuat konsep baru yang digagas olehnya. Mengembangkan kebudayaan sekaligus pendidikan, agar terbebas dari hegemoni Barat, dalam lembaga Taman Siswa.

Pendidikan dalam konsep pengembangan masyarakat merupakan dinamisasi dalam pengembangan manusia yang beradab. Pendidikan tidak hanya terbatas berperan pada pengalihan ilmu pengetahuan (Transfer of knowledge) saja, namun juga berfungsi mengembangkan kemampuan dan membentuk watak serta peradaban bangsa Indonesia. Sehingga Ki Hajar Dewantara sangat mempertahankan betul ajaran Timur yang bersumber dari moral Jawa dan diajarkannya dalam Taman Siswa ditengah serangan denasionalisasi kebudayaan. ${ }^{28}$

Taman Siswa hadir sebagai upaya menolak penjajahan dalam bidang pendidikan sambil dalam praktiknya memelihara budaya Jawa.Taman Siswa berupaya membentuk karakter bangsa dengan mempertahankan ciri khasnya dalam bidang kesenian. Taman Siswa hadir dalam pembelaannya

${ }^{26}$ Erna Nurkholida, "PERSPEKTIF JAWA (Studi Pemikiran Ki Hajar Dewantara)," Cendekia 16, no. 2 (2018): 397.

${ }^{27}$ Dewantara, Karya Ki Hadjar Dewantara Bagian II: Kebudayaan, 4.

${ }^{28}$ Ivan Riyadi, "MANAJEMEN PENDIDIKAN BERMUATAN ANTROPOLOGI, AGAMA DAN SOSIAL," Cendekia 17, no. 2 (2019): 302.

Kodifikasia: Jurnal Penelitian Islam, Volume, 14 No. 1 Tahun 2020 
terhadap pendidikan masyarakat pribumi. Taman Siswa adalah lembaga modern kala itu yang berhasil memadukan konsep pendidikan global dan lokal,

Setelah mengalami kemajuan yang hebat, seiring berjalannya waktu Taman siswa mengalami kemunduran. Mulai dari pergeseran makna filosofi ajaran yang berbeda dari sebelumnya. Dahulu, hubungan guru dengan muridnya bagaikan orang tua dengan anak. Sekarang, guru ke rumah siswa hanya ketika siswa tersebut memiliki masalah dalam proses pembelajaran, atau ketika siswa sedang sakit berat dan jangka lama.

Kemunduran berikutnya mengenai pelaksanaan pembelajaran, yang awalnya dilaksanakan setiap bulan pada rebo wage dan selasa kliwon, saat ini hanya dilakukan pada saat acara-acara besar saja. Jadi penerapan panca dharma Tamansiswa ${ }^{29}$ menjadi terganggu. Dan juga persaingan dalam kualitas pendidikan yang sulit untuk diikuti. Taman siswa dengan swastanya dan lembaga lain dengan negerinya atau mendapat bantuan dari pemerintah Indonesia. Sehingga berkembanglah lembaga pendidikan negeri yang disiapkan pemerintah Indonesia melalui berbagai skema kebijakan, dengan tidak memperhatikan pendidikan Taman Siswa yang sudah ada.

Padahal taman siswa berhasil menggabungkan konsep glokalisasi dengan baik. Mempertahankan lokalitas masyarakat Indonesia yang ada dengan mempertahankan local assets, traditions, values and beliefs yang sudah penulis jelaskan diatas kemudian membuka kran lebar-lebar terhadap perkembangan pendidikan dan kebudayan dari luar, dengan syarat menerima secara kritis (tidak hanya menerima mentah-mentah) segala yang dari luar baik aspek ekonomi, sosial-budaya dan akademik untuk kemajuan kebudayaan nasional Indonesia.

Padahal jika dicermati lebih lanjut, konsep Taman Siswa sangat cocok diterapkan di pendidikan di Indonesia yang kondisinya sangat multikultural dan berkembang berbagai macam agama dengan dasar Ketuhanan yang Maha Esa. Ajaran sekulerisme ${ }^{30}$ yang diterapkan oleh Ki Hajar Dewantara, merasuk pada konsep pendidikan Taman Siswa. Dengan tidak meneguhkan

${ }^{29}$ Isi Pancadharma, yaitu: 1. Kodrat Alam. Merupakan perwujudan kekuasaan Tuhan yang artinya manusia bersatu dengan alam. 2. Kemerdekaan. Merupakan karunia Tuhan yang memberikan hak mengatur hidupnya sendiri. 3. Kebudayaan. Keharusan memelihara nilai-nilai dan bentuk-bentuk kebudayaan nasional. 4. Kebangsaan. Rasa satu bersama bangsa sendiri dalam suka, duka dan kehendak dalam mencapai kebahagiaan hidup lahir-batin seluruh bangsa. 5. Kemanusiaan. Kemanusiaan ialah darma tiap manusia dari keluhuran akal-budinya. Keluhuran akal-budi menimbulkan rasa dan laku kasih-sayang terhadap sesame manusia dan semua makhluk.

${ }^{30}$ Jose Cassanova, "Rethinking Secularization: A Global Comparative Perspective," in Religion, Globalization and Culture, ed. Peter Beyer and Lori Beama (Leiden: Koninklijke Brill NV, 2007), 101. 
ajaran Islam (namun tetap religius) pada konsep pendidikan yang digagasnya. Agama masuk dalam ruang private, dimulyakan, sedangkan pendidikan dan kebudayaan masuk dalam ruang publik, untuk perkembangan peradaban Indonesia.

Ki Hajar Dewantara termasuk orang yang tidak menyetujui adanya peneguhan kembali piagam jakarta. Ki Hajar Dewantara bersama dengan Douwes Dekker dan Tjipto Mangunkusumo, bekerjasama dan berpengaruh terhadap pemikiran dari Soekarno. Di dalam ide-ide mereka Soekarno menemukan pembenaran bagi suatu bentuk nasionalisme yang tidak mengandung komitmen tertentu terhadap Islam, teori perjuangan kelas, maupun kaitan formal dengan kelompok etnik tertentu.

Sistem Taman Siswa yang menolak Islam pembaharu dan memakai kebudayaan jawa sebagai dasar filosofis bagi ciri nasional yang baru, mendapat sambutan positif dari Soekarno. Dengan cara menyerap ide-ide Hindu, Budha, Islam dan Barat ke dalam suatu sintesis yang unik yang mereka anggap memuaskan, seharusnya cocok menjadi model pendidikan di seluruh Indonesia. ${ }^{31}$

\section{Revitalisasi Pemikiran Ki Hajar Dewantara}

Bagaimana revitalisasi pemikiran Ki Hajar Dewantara yang memadukan antara global dan local di era modern ini? Gambar di bawah ini diharapkan memudahkan pembaca untuk memahami revitalisasi pemikiran Ki Hajar Dewantara tentang Glokalisasi Pendidikan.

${ }^{31}$ M. C. Ricklefs, Sejarah Indonesia Modern, ed. Dharmono Hardjowidjono (yogyakarta: Gadjah Mada University Press, 1998).

Kodifikasia: Jurnal Penelitian Islam, Volume, 14 No. 1 Tahun 2020 


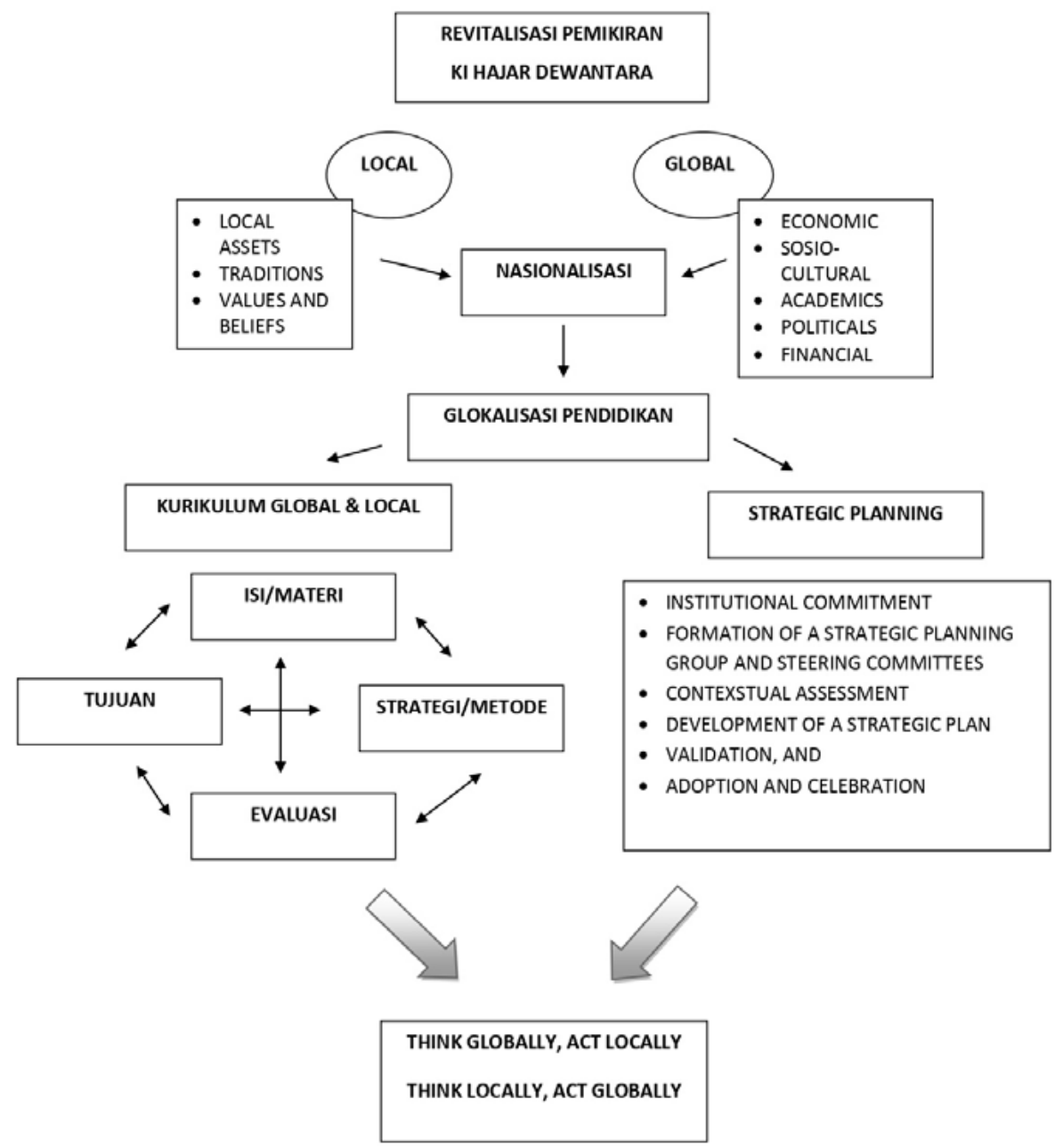

Gambar 1 Revitalisasi Pemikiran Ki Hajar Dewantara

\section{Revitalisasi aspek Global}

Ada 3 tinjauan dalam mengkaji globalisasi yang berpengaruh terhadap pendidikan, yaitu: ekonomi, sosial budaya dan akademik. Revitalisasi ini tujuan akhirnya untuk meletakkan dasar pondasi globalisasi untuk membentuk konsep glokalisasi pendidikan yang mengambil inspirasi dari pemikiran Ki Hajar Dewantara. Dalam bidang ekonomi, hendaknya pendidikan memperhatikan betul mengenai revolusi industri 4.0. Era Industri 4.0 ditandai dengan terjadinya digitalisasi dan pemanfaatan kecerdasan buatan (artificial intelligence) secara massif di berbagai sektor kehidupan manusia, terutama di bidang ekonomi. Hendaknya pendidikan aspek global nantinya juga tanggap terhadap revolusi industri 4.0. bahkan 
konsep yang terbaru, adanya society 5.0 era dimana semua teknologi adalah bagian dari manusia itu sendiri

Dalam bidang Sosial budaya, hendaknya kebudayaan barat dan juga tradisi pemikiran dari barat kita pelajari dengan totalitas. Banyak kaum orientalis mengkaji timur sebagai objek. Era sekarang ini, sudah saatnya kita mengkaji barat sebagai objek kajian kita. Agar kita bisa memperoleh intisari dari kemajuan kebudayaan dan pemikiran barat. Timur yang terkenal dengan mistisnya, harus dilengkapi dengan pemikiran rasionalitas khas Barat. Sehingga muncul integrasi antara ilmu agama dan ilmu umum.

Dalam bidang akademik banyak yang perlu kita serap dari globalisasi, yaitu: adopsi kurikulum luar misal kurikulum cambridge, oxford, harvard atau milik negara finlandia; penguasaan bahasa asing melalui TOEFL, TOAFL, IELTS, dan sebagainya; penjamin mutu dunia semisal ISO, demin, AUNQA, dan sebagainya; kecanggihan teknologi dan informasi; berfikir kritis dan kolaboratif, Pertukaran Pelajar; SCOPUS index; dan sebagainya.

Pendidikan global hendaknya juga memperhatikan Keterampilan abad 21 adalah (1) life and career skills, (2) learning and innovation skills, dan (3) Information media and technology skills. Ketiga keterampilan tersebut dirangkum dalam sebuah skema yang disebut dengan pelangi keterampilan pengetahuan abad 21/21st century knowledge-skills rainbow (Trilling dan Fadel, 2009). ${ }^{32}$ Skema tersebut diadaptasi oleh organisasi nirlaba p21 yang mengembangkan kerangka kerja (framework) pendidikan abad 21 ke seluruh dunia melalui situs www.p21.org yang berbasis di negara bagian Tuscon, Amerika. Adapun konsep keterampilan abad 21 dan core subject 3R, dideskripsikan berikut ini. Gambar 2.2 menunjukkan skema pelangi keterampilan-pengetahuan abad 21.

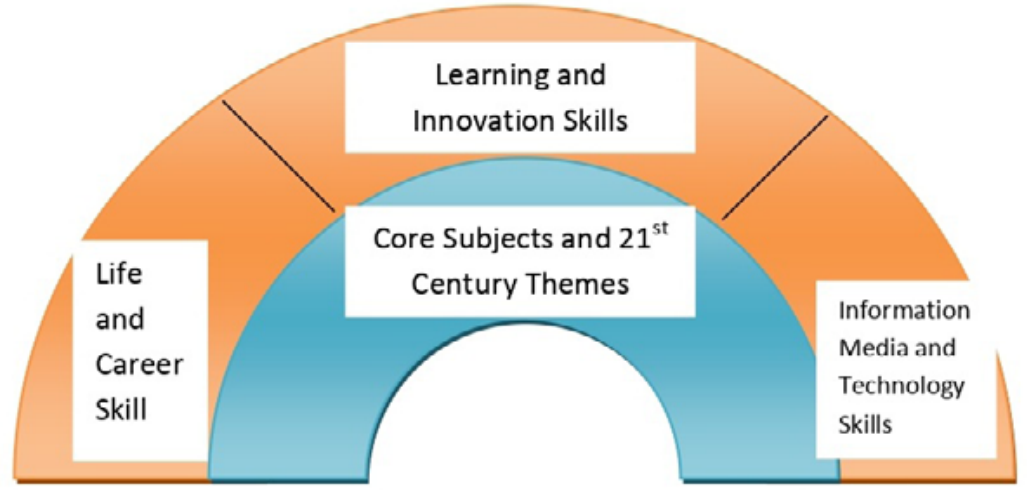

Gambar 2 Pelangi Keterampilan Pengetahuan Abad 21 2009.

${ }^{32}$ Bernie Trilling and Charles Fadel, 21st Century Skills: Learning for Life in Our Times, 
Pada skema yang dikembangkan oleh p21 diperjelas dengan tambahan core subject 3R. dalam konteks pendidikan, 3R adalah singkatan dari reading, writing dan arithmatik, diambil lafal " $\mathrm{R}$ " yang kuat dari setiap kata. Dari subjek reading dan writing, muncul gagasan pendidikan modern yaitu literasi yang digunakan sebagai pembelajaran untuk memahami gagasan melalui media kata-kata. Dari subjek aritmatik muncul pendidikan modern yang berkaitan dengan angka yang artinya bisa memahami angka melalui matematika.

Dalam pendidikan, tidak ada istilah tunggal yang relevan dengan literasi (literacy) dan angka (numeracy) yang dapat mengekspresikan kemampuan membuat sesuatu (wrighting). 3R yang diadaptasi dari abad 18 dan 19 tersebut, ekivalen dengan keterampilan fungsional literasi, numerasi dan ICT yang ditemukan pada sistem pendidikan modern saat ini. Selanjutnya, untuk memperjelas fungsi core subject 3R dalam konteks 21 st century skills, 3R diterjemahkan menjadi life and career skills, learning and innovation skills dan information media and technology skills Penjelasan tentang keterampilan menurut Trilling and Fadel adalah sebagai berikut: ${ }^{33}$

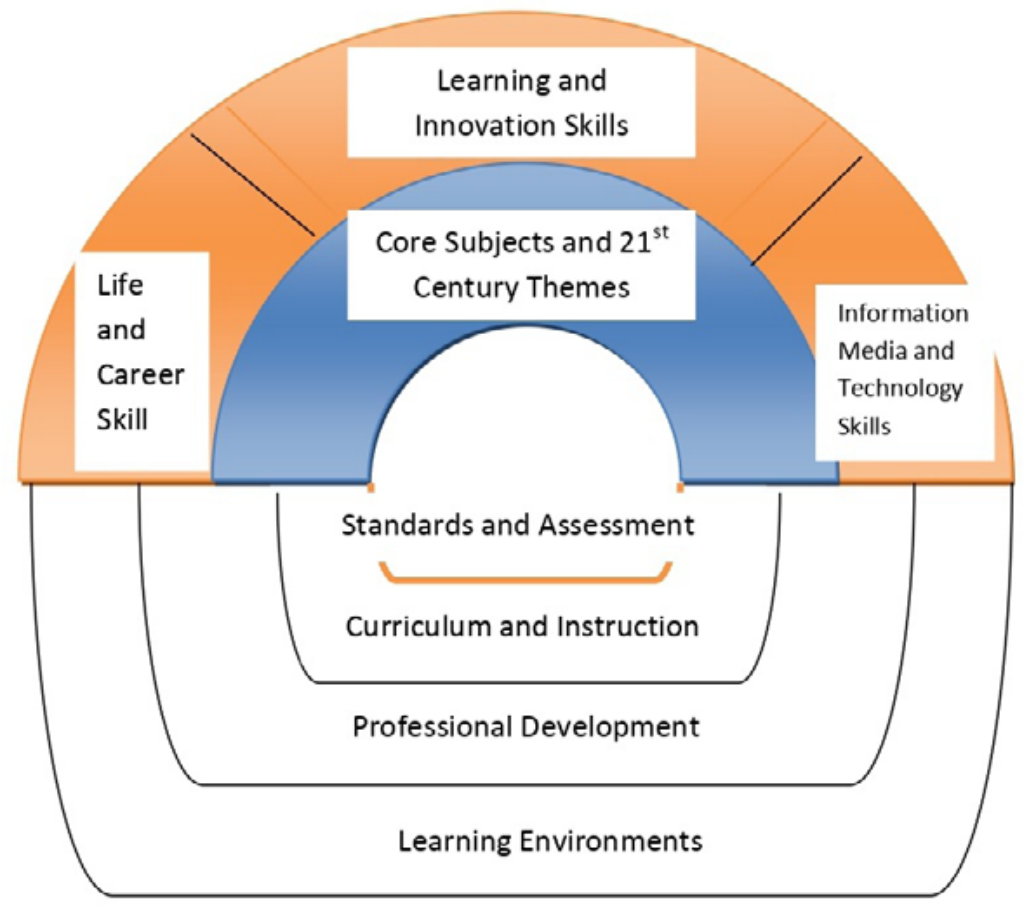

Gambar 3 Framework Pembelajaran Abad ke-21

${ }^{33}$ Trilling and Fadel, 47.

Kodifikasia: Jurnal Penelitian Islam, Volume, 14 No. 1 Tahun 2020 
Dengan turunannya menurut BSNP, yaitu:

a) Kemampuan berpikir kritis dan pemecahan masalah (Critical-Thinking and Problem-Solving Skills), mampu berfikir secara kritis, lateral, dan sistemik, terutama dalam konteks pemecahan masalah;

b) Kemampuan berkomunikasi dan bekerjasama (Communication and Collaboration Skills), mampu berkomunikasi dan berkolaborasi secara efektif dengan berbagai pihak;

c) Kemampuan berpikir kritis dan pemecahan masalah (Critical-Thinking and Problem-Solving Skills), mampu berfikir secara kritis, lateral, dan sistemik, terutama dalam konteks pemecahan masalah;

d) Kemampuan berkomunikasi dan bekerjasama (Communication and Collaboration Skills), mampu berkomunikasi dan berkolaborasi secara efektif dengan berbagai pihak;

e) Kemampuan mencipta dan membaharui (Creativity and Innovation Skills), mampu mengembangkan kreativitas yang dimilikinya untuk menghasilkan berbagai terobosan yang inovatif;

f) Literasi teknologi informasi dan komunikasi (Information and Communications Technology Literacy), mampu memanfaatkan teknologi informasi dan komunikasi untuk meningkatkan kinerja dan aktivitas sehari-hari

g) Kemampuan belajar kontekstual (Contextual Learning Skills), mampu menjalani aktivitas pembelajaran mandiri yang kontekstual sebagai bagian dari pengembangan pribadi, dan

h) Kemampuan informasi dan literasi media, mampu memahami dan menggunakan berbagai media komunikasi untuk menyampaikan beragam gagasan dan melaksanakan aktivitas kolaborasi serta interaksi dengan beragam pihak.

\section{Revitalisasi aspek Lokal}

Dalam glokalisasi pendidikan, aspek lokalitas yang dipertahankan meliputi local assets, traditions, values and beliefs. Ketiga aspek ini akan penulis revitalisasi untuk kemajuan pendidikan di Indonesia yang mengambil inspirasi dari pemikiran Ki Hajar Dewantara.

Pertama, local assets. Pengembangan Bahasa dan aksara lokal, Indonesia memiliki 746 Bahasa lokal dan lebih dari 12 aksara lokal semisal aksara jawa, sunda, bali, mandaling, toba dan lain sebagainya. Namun sayang, aksara-aksara lokal tersebut tidak menjadi garapan serius bagi pendidikan di Indonesia. Banyak aksara yang hilang dan tidak dipelajari oleh generasi milenial. Glokalisasi pendidikan hendaknya hadir untuk mendukung pengembangan Bahasa dan aksara lokal untuk membaca teks-teks kuno, 
karya khas nisantara yang notabene sudah dicuri pihak kolonial Belanda. Naskah-naskah kuno tersebut sebagian tersimpan rapi dalam british library, yang sebenarnya bisa kita gunakan untuk modal kebangkitan lokalitas Indonesia. Syaratnya tentu, dalam pendidikan Indonesia melakukan revitalisasi berupa penguasaan bahasa dan aksara lokal.

Setiap wilayah ataupun negara pasti mempunyai tata cara atau adat istiadat tersendiri, dari negara satu ke negara yang lain akan kita ketemukan banyak perbedaannya. Termasuk Indonesia, demi menghalau laju globalisasi yang menghegemoni, kita harus tetap memperhatikan kodrat manusia Indonesia yang diatur dalam adat-istiadat, baik peraturan tertulis maupun tidak tertulis untuk menjadi manusia Indonesia seutuhnya dengan menguasahi kebudayaannya. Misalkan menjadi wanita jawa, menjadi anak Indonesia, menjadi penguasa perspektif sunda, dan sebagainya. Hal tersebut dapat diwujudkan melalui glokalisasi pendidikan.

Kedua, traditions. Di Indonesia banyak sekali tradisi yang berkembang baik secara lisan maupun tulisan. Tradisi-tradisi ini dikombinasi dengan pendidikan, agar tercipta sebuah glokalisasi pendidikan. Misalnya; lembaga pendidikan menggunakan permainan tradisional, segala macam kesenian lokal bisa berupa topeng, tari-tarian, musik, tradisi fashion atau pakaian yang bisa kita pelajari atau kita gunakan saat sekolah, terus menjaga radisi pengobatan nenek luhur, mengembangkan pula tradisi ekonomi, sosialbudaya, politik yang rekam jejaknya khas dari Indonesia.

Ketiga, values and beliefs. Di Indonesia banyak sekali pitutur luhur yang bisa kita gunakan sebagai panutan atau pedoman bagi pendidikan kita. Misalkan pitutur luhur yang digagas oleh Ki Hajar Dewantara mengenai nang, ning, nung; ing ngarso sung tulodho, ing madyo mangunkarso, tut wuri handayani; Ngandel, kandel, kendel dan bandel; Momong, among dan ngemong; Tetep, antep dan mantep. Ataupun pitutur lain semisal ungkapan eling lan waspodo, nrimo ing pandum, welas asih, dan lain sebagainya. Mengembangkan moral ketimuran, adat istiadat, unggah-ungguh, adab dan ilmu jiwa dalam perspektif lokalitas Indonesia.

Kearifan lokal merupakan bentuk dialektika antara manusia dengan pengetahuan kehidupan. Pengetahuan yang diambil dari kehidupan di mana manusia itu berada kemudian direfleksikan untuk membantu manusia memaknai kehidupan. Sebagai pedoman masyarakat, selanjutnya kearifan lokal memberi panduan yang jelas ranah-ranah yang dapat dijangkau oleh tingkah laku manusia.

Dalam proses terbentuknya, kearifan lokal tidak dikonsepsikan secara individu namun membutuhkan peran komunal yakni masyarakat. Selanjutnya kearifan lokal menjadi bagian dari budaya untuk kemudian 
menjadi identitas bahkan karakter suatu masyarakat. Karenanya, antara kearifan lokal dan budaya merupakan hubungan antara anak dengan induknya. Kearifan lokal tidak lain adalah bagian dari budaya.

Nilai budaya adalah lapisan abstrak dan luas ruang lingkupnya. Tingkat ini adalah ide-ide yang mengkonsepsikan hal-hal yang paling bernilai dalam kehidupan masyarakat. Suatu sistem nilai budaya terdiri atas konsepsikonsepsi yang hidup dalam pikiran sebagian besar warga masyarakat mengenai hal-hal yang harus mereka anggap bernilai dalam hidup. Oleh karena itu, suatu sistem nilai kebudayaan biasanya berfungsi sebagai pedoman tertinggi bagi kelakuan manusia. Sistem kelakuan manusia lain yang tingkatannya lebih konkret, seperti aturan-aturan khusus, hukum, dan norma-norma, semuanya juga berpedoman pada nilai budaya itu. nilai budaya yang dapat mendorong pembangunan, di antaranya sifat tahan penderitaan, berusaha keras, toleran terhadap pendirian atau kepercayaan orang lain, dan gotong-royong. ${ }^{34}$

Pendidikan berbasis kearifan lokal adalah pendidikan yang mengajarkan peserta didik untuk selalu lekat dengan situasi konkret yang mereka hadapi. Paulo Freire menyebutkan, dengan dihadapkan pada problem dan situasi konkret yang dihadapi, peserta didik akan semakin tertantang untuk menanggapinya secara kritis. Hal ini selaras dengan pendapat Suwito yang mengemukakan pilar pendidikan kearifan lokal meliputi:

a) Membangun manusia berpendidikan harus berlandaskan pada pengakuan eksistensi manusia sejak dalam kandungan,

b) Pendidikan harus berbasis kebenaran dan keluhuran budi, menjauhkan dari cara berpikir tidak benar dan grusa-grusu atau waton sulaya,

c) Pendidikan harus mengembangkan ranah moral, spiritual (ranah afektif) bukan sekedar kognitif dan ranah psikomotorik, dan

d) Sinergitas budaya, pendidikan dan pariwisata perlu dikembangkan secara sinergis dalam pendidikan yang berkarakter. ${ }^{35}$

\section{Penerapan Glokalisasi Pendidikan melalui Perencanaan Strategis}

Perencanaan strategis yaitu menilai situasi saat ini dari suatu organisasi atau institusi, menetapkan/mengatur ulang pernyataan visi dan misi, dan mendefinisikan tujuan strategis, sasaran, dan musyawarah program prioritas yang akan memungkinkan untuk mencapai sasaran dan sasaran strategis tersebut. Dengan perencanaan strategis, lembaga pendidikan

\footnotetext{
${ }^{34}$ Koentjaraningarat, Kebudayaan, Mentalitas, Dan Pembangunan (Jakarta: Gramedia,
} 1984), 8-25.

${ }^{35}$ Wagiran and dkk, "Pengembangan Model Pendidikan Kearifan Lokal Di Wilayah Provinsi DIY Dalam Mendukung Perwujudan Visi Pembangunan DIY Menuju Tahun 2025” (Yogyakarta, 2010), 15.

Kodifikasia: Jurnal Penelitian Islam, Volume, 14 No. 1 Tahun 2020 
dapat memahami di mana mereka berada memenuhi misi mereka dalam tujuan pendidikan untuk negara-bangsa tertentu. Dalam lingkungan baru yang dipengaruhi oleh globalisasi, perencanaan strategis menjadi semakin penting, karena banyak institusi pendidikan di Indonesia dihadapkan pada tantangan untuk merencanakan berdasarkan yang isu-isu terbaru.

Perencanaan ini adalah pendekatan alternatif untuk perencanaan internasionalisasi lembaga pendidikan. Itu adalah alternatif karena itu akan lebih menekankan pada kemitraan glokal, pendidikan glokal program, dan pengembangan glokalisasi pendidikan sebagai orientasi strategis untuk internasionalisasi dalam penelitian, pengajaran, dan fungsi layanan dari lembaga pendidikan. Dalam konteks itu, proses perencanaan glokal harus koheren dan komprehensif, dan termasuk tujuan, sasaran, dan hasil yang terkait untuk pengajaran, penelitian, dan dukungan akademis, dengan tahapan:

Pertama, komitmen kelembagaan. Proses perencanaan glokal membutuhkan komitmen kepemimpinan sebuah lembaga untuk memastikan siap menyediakan semua umber daya yang akan diperlukan untuk implementasi glokalisasi pendidikan. ${ }^{36}$

Kedua, pembentukan kelompok perencanaan strategis dan komite pengarah, serta penilaian kontekstual. Proses perencanaan strategis yang efektif harus dilakukan oleh kelompok perencanaan strategis yang diamanatkan atau gugus tugas yang mewakili berbagai kelompok dan unit utama dari lembaga pendidikan atau perguruan tinggi untuk merancang glokalisasi pendidikan. Sedangkan Penilaian kontekstual harus mengumpulkan informasi tentang persepsi semua pemangku kepentingan internal dan eksternal terkait ke lembaga, termasuk kolaborator potensial untuk program glokalisasi pendidikan. ${ }^{37}$

Ketiga, mengembangkan rencana strategis, serta melakukan Validasi. Setiap unit harus melakukan analisis SWOT sendiri, menetapkan tujuan strategis, tujuan, dan strategi dalam kaitannya dengan tujuan keseluruhan dari proses strategis kelembagaan menuju glokalisasi pendidikan. ${ }^{38}$

Keempat, adopsi dan perayaan. Adopsi rencana strategis untuk glokalisasi pendidikan harus terjadi melalui perayaan, terutama semua yang terlibat dalam proses rasa pencapaian. Perayaan pengembangan dan adopsi rencana strategis dapat membantu menciptakan momentum untuk

${ }^{36}$ Francois, Building Global Education With A Local Perspective: An Introduction To Glocal Higher Education, 174.

${ }^{37}$ Francois, $175-77$.

${ }^{38}$ Francois, $177-78$. 
implementasi awal, dan menetapkan preseden untuk akuntabilitas dan peningkatan kualitas berkelanjutan. ${ }^{39}$

Itulah revitalisasi pemikiran Ki Hadjar Dewantara dengan pendidikan Indonesia saat ini. Dengan semangat menghidupkan kembali kebudayaan lokal nasional demi mencapai kemerdekaan secara lahir dan batin. Konsep pemikiran yang diusung adalah glokalisasi pendidikan, gabungan global dan lokal demi mewujudkan dunia ketiga, dunia yang bisa mempersatukan antara kemampuan global dan lokal. Berprinsip think globally, act locally dan think locally, act globally. Karena kondisi pendidikan Indonesia saat ini, semboyannya sudah dipakai (Tut Wuri Handayani), namun "nyawa"-nya ditinggalkan.

\section{PENUTUP}

\section{Kesimpulan}

Pertama, konsep pemikiran pendidikan Ki Hajar Dewantara berbasis kearifan lokal meliputi 3 hal, yaitu: (1) local assets, mengembangkan bahasa jawa baik secara lisan maupun tulisan, manusia dengan kodratnya sebagai manusia jawa. (2) Traditions, mengembangkan pola permainan tradisional khas jawa, diajarkan aneka kesenian daerah berupa gending, wayang, musik bonang, tari-tarian jaipong, srimpi, tonil, ajaran wirama, dan lain sebagainya. (3) Values and beliefs, jargon atau pitutur luhur yang digunakan oleh Ki Hajar Dewantara semisal: momong, among dan ngemong; tetep, antep dan mantep; neng, ning, nung dan nang, dan lain sebagainya.

Kedua, konsep pemikiran pendidikan Ki Hajar Dewantara berwawasan global meliputi: Bidang ekonomi: Individualisme vs gotong royong. Bidang sosio-cultural yaitu strata sosial vs persamaan derajat. Bidang akademik, dengan mengajarkan bahasa belanda dalam taman siswa, tokoh-tokoh modern pada masa itu, juga banyak yang mempengaruhi pemikirannya, jenjang pendidikan taman siswa yang mirip dengan ajaran Belanda, Materi-materi yang diajarkan dalam taman siswa berupa pengembangan aspek kognitif (rasionalisme), afektif (adab ketimuran) dan psikomotorik (kejuruan).

Ketiga, revitalisasi pemikiran Ki Hajar Dewantara tentang glokalisasi pendidikan, menggunakan teori hermeneutika filosofis, yaitu: revitalisasi aspek global. Ada tiga tinjauan dalam mengkaji globalisasi yang berpengaruh terhadap pendidikan, yaitu: ekonomi, sosial budaya dan akademik. Revitalisasi ini tujuan akhirnya untuk meletakkan dasar pondasi globalisasi dalam membentuk konsep glokalisasi pendidikan yang mengambil inspirasi dari pemikiran Ki Hajar Dewantara. Dengan penerapan glokalisasi

\footnotetext{
${ }^{39}$ Francois, 182.
} 
melalui perencanaan strategis pendidikan yaitu: Komitmen kelembagaan; pembentukan kelompok perencanaan strategis dan komite pengarah, Penilaian kontekstual; Mengembangkan rencana strategis, Validasi; Adopsi dan perayaan. 


\section{DAFTAR RUJUKAN}

Abdullah, M. Amin. "Pendekatan Hermeneutik Dalam Studi Fatwa-Fatwa Keagamaan." In Atas Nama Tuhan, translated by R. Cecep L. Jakarta: Serambi Ilmu Semesta, 2004.

Cassanova, Jose. "Rethinking Secularization: A Global Comparative Perspective." In Religion, Globalization and Culture, edited by Peter Beyer and Lori Beama, 101. Leiden: Koninklijke Brill NV, 2007.

Choiri, Moh. Miftachul, and Aries Fitriani. "PROBLEMATIKA PENDIDIKAN ISLAM SEBAGAI SUB SISTEM PENDIDIKAN NASIONAL DI ERA GLOBAL." Al-Tahrir 11, no. 2 (2011): 303-26.

Choiri, Moh Miftachul. "Quo Vadis Pendidikan Multikultural Dalam Era Global Di Pesantren." Cendekia 9, no. 2 (2011): 193-204.

Dewantara, Ki Hadjar. Karya Ki Hadjar Dewantara Bagian II: Kebudayaan. Yogyakarta: Yayasan Persatuan Tamansiswa, 2011.

—_. Karya Ki Hadjar Dewantara Bagian Pertama: Pendidikan. Yogyakarta: Yayasan Persatuan Tamansiswa, 2011.

Fetel, Pay. "Deconstructing Internationalization: Advocating Glocalization in International Higher Education." Journal of International and Global Studies 8, no. 2 (2017).

Francois, Emmanuel Jean. Building Global Education With A Local Perspective: An Introduction To Glocal Higher Education. New York: Palgrave Macmillan, 2015.

Huda, Muhammad Muchlish. "FISIBILITAS HERMENEUTIKA DALAM PENAFSIRAN AL-QUR'AN.” Dialogia 12 (2014): 67-80.

Iswahyudi. "ITTISHÂL AL-WUJÛD Telaah Hermeneutis Atas Ajaran Mistik Al-Fârâbî." Dialogia, n.d., 146-68.

Kartodirdjo, Sartono. Pengantar Sejarah Indonesia Baru Sejarah Pergerakan Nasional (Jilid 2). Yogyakarta: Penerbit Ombak, 2014.

Koentjaraningarat. Kebudayaan, Mentalitas, Dan Pembangunan. Jakarta: Gramedia, 1984.

Muzakki, Hawwin. "Relasi Pendidikan (Agama) Dan Kebudayaan." Proceedings of Annual Conference for Muslim Scholars 3, no. 1 SE-Articles 
(November 26, 2019). http://proceedings.kopertais4.or.id/index.php/ ancoms/article/view/287.

- Sistem Penilaian Pembelajaran Teori Dan Praktek. Malang: Madani Media, 2019.

Muzakki, Hawwin, and Khoirul Mudawinun Nisa'. "Basis Transformasi Tradisi Pesantren Salaf Di Era Modern (Kajian Semiotika Barthes Dan Dekonstruksi Derrida)." QALAMUNA: Jurnal Pendidikan, Sosial, Dan Agama 12, no. 01 (2020): 91-105. https://doi.org/10.37680/qalamuna. v12i01.304.

Nisa, Khoirul Mudawinun. "GLOKALISASI: MEMBANGUN PENDIDIKAN GLOBAL BERBASIS KEARIFAN LOKAL PADA PONDOK MODERN.” AN-NUHA 5, no. 1 (2018).

Nurkholida, Erna. "PERSPEKTIF JAWA (Studi Pemikiran Ki Hajar Dewantara)." Cendekia 16, no. 2 (2018): 393-407.

Poesponegoro, Marwati Djoened, and Nugroho Notosusanto. Sejarah Nasional Indonesia V. Jakarta: PN Balai Pustaka, 1984.

Ricklefs, M. C. Sejarah Indonesia Modern. Edited by Dharmono Hardjowidjono. yogyakarta: Gadjah Mada University Press, 1998.

Riyadi, Ivan. "MANAJEMEN PENDIDIKAN BERMUATAN ANTROPOLOGI, AGAMA DAN SOSIAL." Cendekia 17, no. 2 (2019): 301-16.

Rohmah, Nihayatur. "AKULTURASI ISLAM DAN BUDAYA LOKAL (Memahami Nilai-Nilai Ritual Maulid Nabi Di Pekalongan).” AlMabsut: Jurnal Studi Islam Dan Sosial 9, no. 2 (2015): 1-19.

Rohmanu, Abid. "HUMAN AGENT DALAM TRADISI FIKIH: Studi Relasi Hukum Islam Dan Moralitas Perspektif Abou El Fadl." Kodifikasia, 7, no. 1 (2013): 2013.

Salsabilah. "PENDIDIKAN KARAKTER ISLAMI BERBASIS NILAINILAI KEARIFAN LOKAL (Penelitian Di SDN 12 Ciseureuh Kahuripan Pajajaran Purwakarta)." Cendekia 17, no. 2 (2019): 269-84.

Syaikhudin, Ahmad. "KONSEP PEMIKIRAN PENDIDIKAN MENURUT PAULO FREIRE DAN KI HAJAR DEWANTORO.” Cendekia 10, no. 1 (2012). 
70 | Hawwin Muzakki

Tasrif, Muhammad. "METODOLOGI FIQH AL-HADÎTH Telaah Hermeneutik Terhadap Pandangan Yûsuf Al-Qardâwî." Dialogia, n.d., 201-25.

Trilling, Bernie, and Charles Fadel. 21st Century Skills: Learning for Life in Our Times, 2009.

Wagiran, and dkk. "Pengembangan Model Pendidikan Kearifan Lokal Di Wilayah Provinsi DIY Dalam Mendukung Perwujudan Visi Pembangunan DIY Menuju Tahun 2025.” Yogyakarta, 2010.

Wijaya, Aksin. Teori Interpretasi Al-Qur'an Ibnu Rushd Kritik IdeologiHermeneutis. Yogyakarta: Kalimedia, 2017. 